\title{
The threat to primates and other mammals from the bushmeat trade in Africa, and how this threat could be diminished*
}

\author{
Evan Bowen-Jones and Stephanie Pendry
}

\begin{abstract}
The threat that the bushmeat trade presents to primates and other taxa was assessed from the literature, including data from markets, village hunting studies and logging concessions in Central and West Africa. In many cases the numbers of both common and protected species of primate being killed throughout the region are thought to be unsustainable. This is also the case for other taxa involved in the bushmeat trade, which crosses geographic, cul-
\end{abstract}

\section{Introduction}

The bushmeat trade occurs across virtually the whole of tropical Africa, Asia and the Neotropics, threatening a multitude of wildlife species (Robinson \& Bennett, in press). Rapidly increasing human populations, with a tendency towards urbanization and improved technology, and commercialization of markets with greater access to formerly remote areas, mean that fewer and fewer areas are immune to the impact of this trade. This paper presents an overview of the economic importance of the bushmeat trade in Central and West Africa, which has been the focus of much recent research, some of which has shown that bushmeat hunting has reached unsustainable levels (Wilkie \& Finn, 1990; Fa et al., 1995). However, it is important to recognize the complexity of a trade that is geographically highly variable, depending on social and cultural factors, topography, available infrastructure and market access (Bowen-Jones, 1998). In addition, when proposing solutions, the importance of the trade to individuals, communities and national economies must be recognized. We evaluate the effect of the trade on different taxa, including primates, which are at particular risk from certain methods of hunting (Oates \&

\footnotetext{
* The views presented in this paper are those of the authors and do not necessarily represent those of Fauna \& Flora International.
}

Evan Bowen-Jones (corresponding author) and Stephanie Pendry Fauna \& Flora International, Great Eastern House, Tenison Road, Cambridge CB1 2DT, UK. Fax: + 441223461 481; e-mail: info@fauna-flora.org. S. Pendry current address: TRAFFIC International, 219c Huntingdon Road, Cambridge CB3 ODL, UK.

Received 25 September 1998. Accepted 5 January 1999 tural and economic boundaries. A suite of measures must be considered to mitigate the effects of this trade, and these measures will have to recognize the local, regional and national socio-economic importance of the trade if they are to result in long-term. conservation success.

Keywords Bushmeat, Central Africa, hunting, primates, sustainability, threats.

Davies, 1986), and suggest ways in which this threat can be reduced.

\section{The importance of bushmeat hunting to local and national economies}

Bushmeat hunting for subsistence is widespread throughout Central and West Africa. However, it is becoming increasingly difficult to distinguish subsistence hunting from commercial hunting because indigenous and village groups supplement their incomes with the sale of bushmeat (Hart, 1978; Hart \& Hart, 1986; Wilkie et al., 1992; Lahm, 1996). For example, Wilkie et al. (1992) reported that hunting had become 'big business' for the BaKouele and BaNgombe pygmies, and now constitutes a major source of revenue. The establishment of permanent settlements along roads, the replacement of traditional weapons with modern ones, the abandonment of traditional beliefs and the participation in a cash economy have often resulted in dependency on the sale of bushmeat (Lahm, 1996).

The key element in the bushmeat trade becoming unsustainable, however, is demand, not technology. Alvard (1995), working with indigenous peoples in the Peruvian Amazon, found that there was no difference between harvest per head for hunters using traditional techniques and those using shotguns, although guns were over four times more efficient than bows. In larger communities, however, the off-take of animals was leading to overexploitation, and near local extinction in some prey species, including the larger primates (black spider monkey Ateles paniscus and red howler monkey Alouatta seniculus). The amount of meat taken was in proportion to the number of consumers. 
The majority of hunting in Central and West African villages is often for cash rather than for protein. Infield (1988) found that, in addition to the maximum of $100 \mathrm{~kg}$ of bushmeat consumed per inhabitant per year, bushmeat sales may represent 33 percent of total village income. Even when the predominant source of income in a forested area is from agriculture, bushmeat hunting has become economically important (Prescott et al., 1994; Muchaal \& Ngandjui, 1995). It also represents a method of controlling crop pests as well as raising money to pay taxes and for schooling (Anstey, 1991).

It is no surprise, given regional sales (bushmeat taken from the Korup National Park was worth \$US430,000 per year according to Infield [1988]), that the trade makes a significant contribution to national economies. Estimates of this contribution range from \$US24 million per annum from rural consumption in Gabon (not accounting for local economic return and direct sales to restaurants) to \$US42 million per annum in Liberia (including subsistence bushmeat) and to \$US117 million per year in Côte d'Ivoire (Anstey, 1991; Steel, 1994; Fa, in press). Anstey also calculated that the replacement of bushmeat with a domestic meat alternative would involve the expenditure of \$US100 million per annum in Liberia.

\section{Factors contributing to the increase in the bushmeat trade}

\section{Urbanization, access to formerly remote areas and transport}

The heavy urban bias in the populations of some countries in the region has led to increased demand for bushmeat. According to Steel (1994), 60 per cent of Gabon's 1.1 million inhabitants live in urban areas, and in 198741 per cent of Liberia's 2.4 million inhabitants lived in cities (Anstey, 1991).

Centres of bushmeat commerce are to be found throughout the region, from Gabon to Democratic Republic of Congo (Steel, 1994; J. M. Thompson, pers. comm.; Plate 1). The demand for bushmeat is constant, and when transport becomes available (whether it be trucks, boats, motorbikes or trains), bushmeat traders inevitably use it (Wilkie et al., 1992; Blake, 1993; Steel, 1994; Bennett Hennessey, 1995; Pearce \& Ammann, 1995; Malonga, 1996; Vanwijnsberghe, 1996). The supply links from rural areas to towns and cities in a given region are dependent on the available infrastructure. Road access facilitates the export of carcasses and makes remote areas the focus of commercial hunting, often at unsustainable levels
(Infield, 1988; Gadsby \& Jenkins, 1992; King, 1994). For example, in countries such as Cameroon, which has a good road system, protected areas are becoming increasingly threatened by bushmeat hunting, whereas Butynski \& Koster (1994), working on Bioko, noted that the absence of roads and settlements on the eastern, southern and western slopes of Pico Basile and over the southern third of the island, makes these regions subject to less hunting pressure'.

\section{Logging}

There is also a correlation between logging activity and increased bushmeat trading. This, again, is a result of the linking of once-remote forest areas to commercial centres, via logging roads and trucks, which provide the physical means to transport game. The commercial off-take is often combined with demand that is created by the work force in situ, and sometimes met by permitting hunting within the logging concession (Oates \& Davies, 1986; Stromayer \& Ekobo, 1991; Sayer et al., 1992; Hall, 1993; Blake, 1994; Bennett Hennessey, 1995; Pearce \& Ammann, 1995; Pearce, 1996; Usongo \& Curran, 1996). Not only do such areas supply the urban centres of the rest of the country in question (Blake, 1993; Bennett Hennessey, 1995; Pearce \& Ammann, 1995; Usongo \& Curran, 1996; Malonga, 1996), but sometimes those of neighbouring countries (Stromayer \& Ekobo, 1991; Wildlife Conservation Society, 1996).

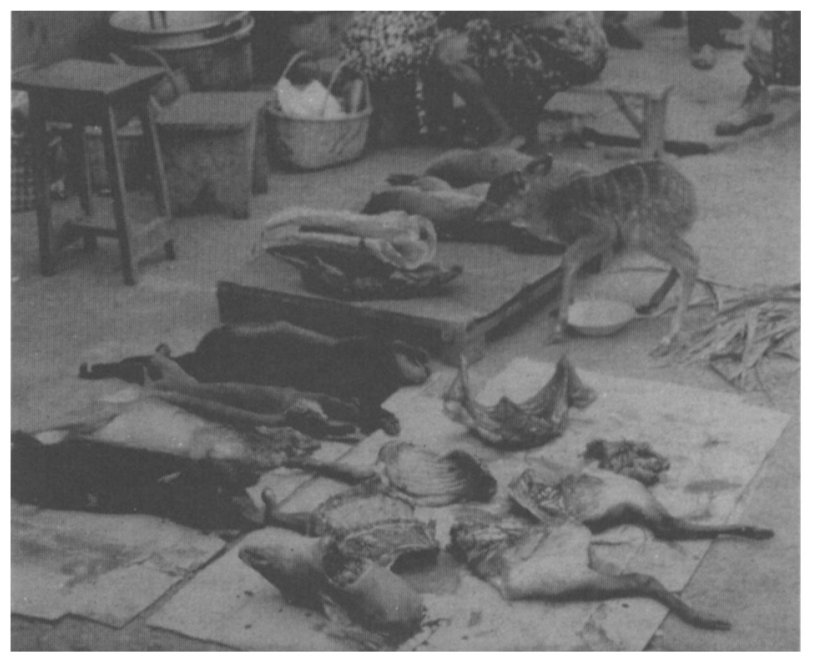

Plate 1 Bushmeat markets often sell their wares in a variety of ways, from entire carcasses to chunks of meat, or even live animals (ECOFAC Programme: University of Gembloux). 


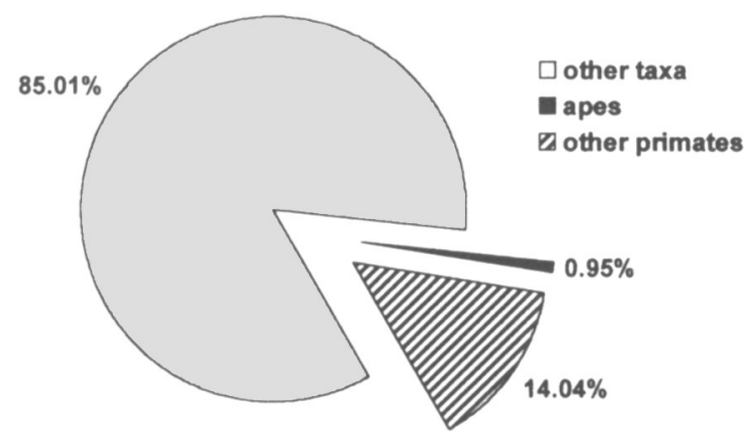

Fig. 1 Composition of market data from four countries in West and Central Africa showing primate and non-primate components $(n=34,302)$. Data from Anstey (1991), Bennett Hennessey (1995), Fa et al. (1995), Malonga (1996) and Steel (1994).

\section{The effect of the bushmeat trade on different taxa}

The effect of the bushmeat trade on the species involved has yet to be determined. Where research has taken place, the results have shown that this trade is one of the major threats to the survival of rain-forest fauna in Africa. Wilkie et al. (1998) stated that it is not habitat loss but defaunation that poses the greatest immediate threat to animal conservation in the forests of West and Central Africa. The relationship between density reduction and degree of threat is not a simple one and requires further detailed investigation because some species may persist at low densities after hunting.

In order to evaluate the effects of the bushmeat trade we looked at data collected in market studies across the region. Information was collated from published sources (reports and papers) where studies had lasted for more than 2 months and considered trade across taxa. We evaluated the data on apes, other primates and non-primates separately. The results are shown in Figs 1-4.

\section{The effect of the commercial bushmeat trade on apes}

The hunting of apes and the sale of their meat for human consumption have been reported from many countries including Nigeria (McFarland, 1994); Central African Republic (Goldsmith, 1995); Congo-Brazzaville (Redmond, 1989); Democratic Republic of Congo (Basabose et al., 1995; Ammann, 1998; J. M. Thompson, pers. comm.); Gabon (Harcourt, 1980); and Equatorial Guinea (Sabater, 1981; Fa et al., 1995). This off-take from local hunting has also been shown to threaten ape populations in at least one case in the Motaba region of north-east Congo. There, Kano \& Asato (1994) esti-

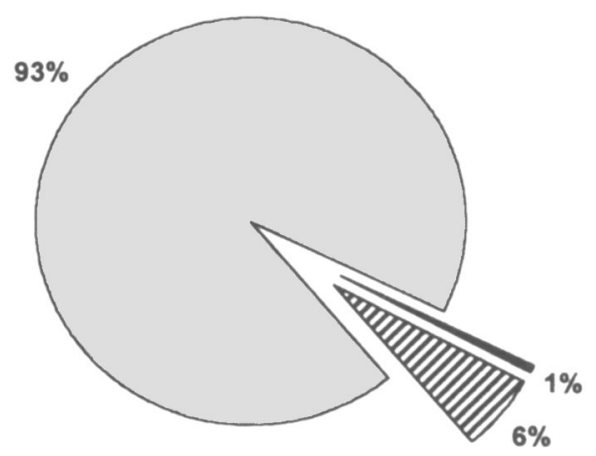

Fig. 2 Composition of village hunting data from two studies in Central Africa showing primate and non-primate components ( $n=2584$ ). Data from Dethier (1995) and Vanwijnsberghe (1996).

mated that 0.02 chimpanzees and 0.01 gorillas per $\mathrm{sq} \mathrm{km}$ were hunted per year. This would mean that annual off-take from the population was 5-7 percent, surpassing annual population increase. (This area has densities of 0.3 chimpanzees and 0.2 gorillas per sq km [Kano \& Asato, 1994], which is fairly low compared with maximum gorilla densities of 2.6 per sq $\mathrm{km}$ [Fay, 1989].)

However, accurate data for ape off-take over large areas are rare. Part of the problem is the wide range of population estimates for the African great apes (Kemf \& Wilson, 1997). Also, the indications are that chimpanzee numbers are higher in parts of their range than previously thought (Harcourt \& Ellerton, 1995), and there is evidence that secondary forest can benefit gor-illas (Tutin \& Fernandez, 1984). (As a result, there has been some debate over the conservation status of the great apes [Harcourt, 1995].) Problems in estimating the number of animals being killed per year could be further compounded by regional variation in local taboos, religion, availability

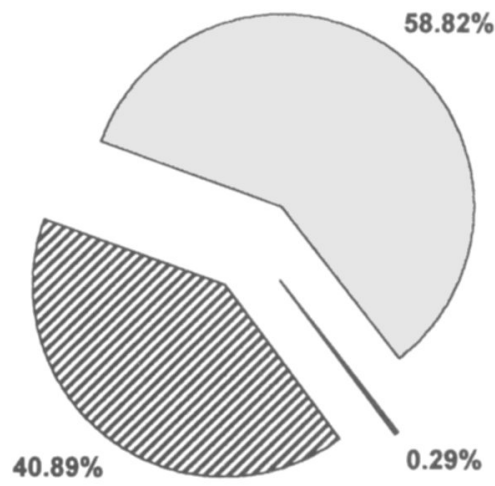

Fig. 3 The primate and non-primate components of bushmeat from logging camp data in Gabon: Gongue $(n=1037)$. Data from Boussougou (1994). 


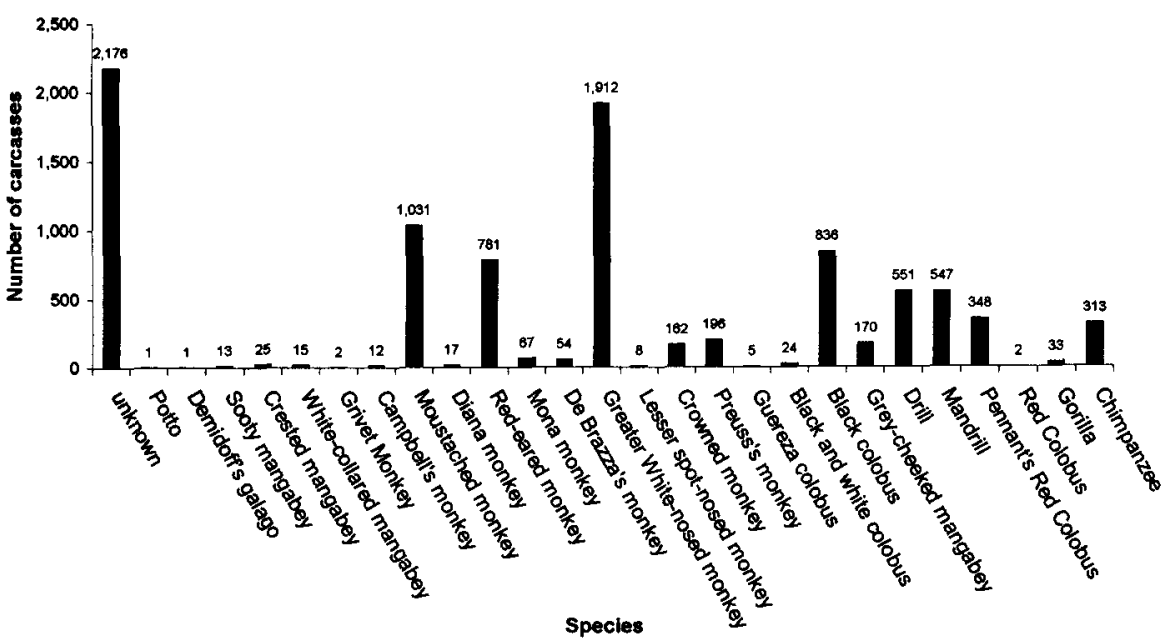

Fig. 4 Composition of primate kills from carcass data in five Central and West African countries $(n=9337)$. Data from Anstey (1991), Boussougou (1994), Steel (1994), Bennett Hennessey (1995), Dethier (1995), Fa et al. (1995), Malonga (1996) and Vanwijnsberghe (1996).

of ammunition and guns, closed seasons, and ease of hunting depending on seasons (Oates \& Davies, 1986; Gadsby, 1990; Gadsby \& Jenkins, 1992; Blake, 1994; Gippoliti \& Dellomo, 1995).

The review of the market studies seems to indicate that, despite the number of animals being hunted, the percentage of apes taken is low (Fig. 1). This does not indicate that there is no threat to ape populations or species, but rather shows the scale of the commercial bushmeat trade as a whole. Most of the quantitative data have been recorded as numbers of carcasses. However, if the weight of animals is taken into account, the percentage of biomass from apes would be expected to be higher. Malonga's (1996) study was one of the largest of those where data on bushmeat were collected by weight. His figures from the markets in Brazzaville, Congo, indicated that the gorilla and chimpanzee carcasses recorded (approximately 1.94 per cent of the total number of animal carcasses), weighed $2036.7 \mathrm{~kg}$. This represented 2.23 per cent of the total weight of meat sold and gives a more accurate account of the biological significance of the proportion of ape meat in this study.

There are other reasons why the numbers of apes killed for bushmeat might be under-represented in market studies:

- Market vendors questioned about the animals that they sell often know that it is illegal to hunt species such as gorilla, chimpanzee, elephant and buffalo (Steel, 1994).

- In some areas the inconvenience of carrying large carcasses (such as gorillas) out of the forest, and the fact that the meat is favoured, means that they are often eaten on the spot, or in the village $(\mathrm{J} . \mathrm{Fa}$, pers. comm.).

- In order to preserve large volumes of meat until it can be sold, parts are often smoked, which makes the identification of species and the number of individual animals taken difficult to determine from market data (Wilson \& Wilson, 1991; Pearce \& Ammann, 1995; Malonga, 1996; Plate 2).

- In some areas the size of large animals, combined with the illegality of hunting these species, may mean that poachers sell whole, fresh carcasses immediately. Large, protected species may therefore be underrepresented in village hunting data (Njiforti, 1996).

- Figures indicating direct hunting effects will not have taken into account the secondary impact on ape populations of 'accidental' death from traps and snares. Heather Eves (pers. comm.) in Democratic Republic of Congo (DRC), noted that gorillas, in particular, are often injured in trap lines and this may lead to death. J. M. Thompson (pers. comm.) indicated that the situation in DRC is similar with regard to bonobo Pan paniscus, and other workers report this in chimpanzee populations in Uganda (V. Reynolds, pers. comm.).

There is anecdotal evidence that there may be limited, targeted hunting for apes. However, the authors were unable to find any reliable, quantitative evidence to support this.

The effect of the commercial bushmeat trade on other primates

Oates \& Davies (1986) stated that 'large-bodied primates dependent on mature forest face possible extinction'. They specifically mentioned red colobus Procolobus spp. and Diana monkey Cercopithecus diana. Robinson (1995) surmised, from Neotropical work, that hunters target preferentially animals over $1 \mathrm{~kg}$ in weight, and therefore one might expect taxa containing medium- and large-bodied species to be equally at risk. However, primates are particularly susceptible to hunting with firearms (King, 1994). 
Figures $1-3$ show the relative percentage of primates taken in the bushmeat trade and the numbers of primate species other than apes that were recorded. Figure 4 breaks these data down further, where possible, into the different primate species seen in the market studies. Under-representation may also have occurred for some of these species given that the largest grouping is for unidentified/smoked meat. Species affected by the trade will vary from region to region and not all are represented here. Table 1 gives a list of all primate species mentioned in the literature cited together with their IUCN (1996) threat rating.

The predominance of the greater white-nosed monkey Cercopithecus nictitans and the moustached monkey C. cephus in trade probably reflects their abundance (Fig. 4; Plate 3). White (1994) found that these two species were among three that showed little change in density between heavily and lightly hunted areas in Gabon. However, the hunting of the more common primates can be non-sustainable. In Equatorial Guinea, Fa et al. (1995) found that five species were being hunted at unsustainable levels: red-eared monkey Cercopithecus erythrotis; C. nictitans; crowned monkey C. pogonias; Preuss's monkey $C$. preussi; and the drill Mandrillus leucophaeus, with the first three being killed at 28 times the sustainable level. Figure 4 shows that the total number of drills killed exceeds the combined total for chimpanzees and gorillas. The drill is the most endangered primate in Africa (IUCN, 1996). In Korup National Park, Cameroon, Infield (1988) found that 7 per cent of hunters' income resulted from kills of this species. Drills are elusive, and encounters with hunters rare, but when they do occur more than one animal is usually killed: $6-15$ in this case, while King (1994) reported 30 being shot at one time. While some primate species may not face biological extinction as a result of

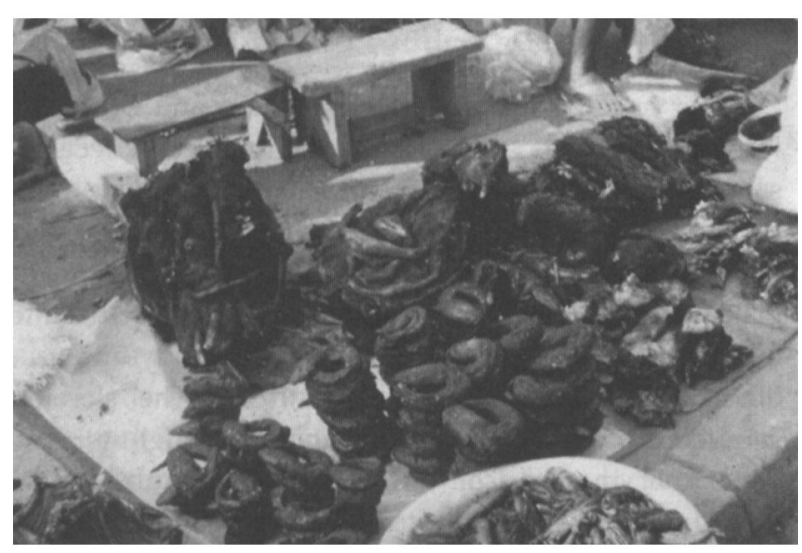

Plate 2 The smoked meat in this market shows how difficult it is to identify the species of origin for this type of product. This has repercussions for the accuracy of some market analyses (ECOFAC Programme: University of Gembloux).
Table 1 Primate species mentioned in 'carcass data' from the literature reviewed, with their respective threat categories

\begin{tabular}{|c|c|c|}
\hline English name & Scientific name & Status \\
\hline \multicolumn{3}{|l|}{ Family: Galagonidae } \\
\hline $\begin{array}{l}\text { Elegant needle- } \\
\text { clawed galago }\end{array}$ & Galago elegantulus & $\begin{array}{l}\text { Lower Risk: near } \\
\text { threatened }\end{array}$ \\
\hline $\begin{array}{l}\text { Allen's squirrel } \\
\text { galago }\end{array}$ & Galago alleni & $\begin{array}{l}\text { Lower Risk: near } \\
\text { threatened }\end{array}$ \\
\hline $\begin{array}{l}\text { Demidoff's } \\
\text { galago }\end{array}$ & Galagoides demidoff & \\
\hline Potto & Perdicticus potto & \\
\hline \multicolumn{3}{|c|}{ Family: Cercopithecidae } \\
\hline Sooty mangabey & Cercocebus atys & $\begin{array}{l}\text { Lower Risk: near } \\
\text { threatened }\end{array}$ \\
\hline $\begin{array}{l}\text { Crested } \\
\text { mangabey }\end{array}$ & Cercocebus galeritis & $\begin{array}{l}\text { Lower Risk: near } \\
\text { threatened }\end{array}$ \\
\hline $\begin{array}{l}\text { White-collared } \\
\text { mangabey }\end{array}$ & Cercocebus mitis & \\
\hline Grivet monkey & $\begin{array}{l}\text { Cercopithecus } \\
\text { aethiops }\end{array}$ & \\
\hline $\begin{array}{l}\text { Campbell's } \\
\text { monkey }\end{array}$ & $\begin{array}{l}\text { Cercopithecus } \\
\text { campbelli }\end{array}$ & \\
\hline $\begin{array}{l}\text { Moustached } \\
\text { monkey }\end{array}$ & $\begin{array}{l}\text { Cercopithecus } \\
\text { cephus }\end{array}$ & \\
\hline Diana monkey & Cercopithecus diana & Vulnerable $(A 1 c+2 c)$ \\
\hline $\begin{array}{l}\text { Red-eared } \\
\text { monkey }\end{array}$ & $\begin{array}{l}\text { Cercopithecus } \\
\text { erythrotis }\end{array}$ & Vulnerable (A1c) \\
\hline Mona monkey & $\begin{array}{l}\text { Cercopithecus } \\
\text { mona }\end{array}$ & \\
\hline $\begin{array}{l}\text { De Brazza's } \\
\text { monkey }\end{array}$ & $\begin{array}{l}\text { Cercopithecus } \\
\text { neglectus }\end{array}$ & \\
\hline $\begin{array}{l}\text { Greater white- } \\
\text { nosed monkey }\end{array}$ & $\begin{array}{l}\text { Cercopithecus } \\
\text { nictitans }\end{array}$ & \\
\hline \multicolumn{3}{|c|}{$\begin{array}{l}\text { Lesser spot-nosed Cercopithecus } \\
\text { monkey petaurista }\end{array}$} \\
\hline $\begin{array}{r}\text { Crowned } \\
\text { monkey }\end{array}$ & $\begin{array}{l}\text { Cercopithecus } \\
\text { pogonias }\end{array}$ & \\
\hline Preuss's monkey & $\begin{array}{l}\text { Cercopithecus } \\
\text { preussi }\end{array}$ & Endangered $(\mathrm{A} 1 \mathrm{~cd}+2 \mathrm{c})$ \\
\hline $\begin{array}{l}\text { Sun-tailed } \\
\text { guenon }\end{array}$ & $\begin{array}{l}\text { Cercopithecus } \\
\text { solatus }\end{array}$ & Vulnerable $(\mathrm{B} 1+2 \mathrm{a}, \mathrm{C} 1)$ \\
\hline Guereza colobus & Colobus guereza & \\
\hline $\begin{array}{l}\text { Black-and-white } \\
\text { colobus }\end{array}$ & Colobus polykomos & $\begin{array}{l}\text { Lower Risk: near } \\
\text { threatened }\end{array}$ \\
\hline Black colobus & Colobus satanas & Vulnerable (A1c) \\
\hline Patas monkey & Erythrocebus patas & \\
\hline $\begin{array}{l}\text { Grey-cheeked } \\
\text { mangabey }\end{array}$ & Lophocebus albigena & \\
\hline Drill & $\begin{array}{l}\text { Mandrillus } \\
\text { leucocephalus }\end{array}$ & $\begin{array}{l}\text { Endangered (A1acd }+ \\
2 c d, C 1+2 a)\end{array}$ \\
\hline Mandrill & Mandrillus sphinx & \\
\hline Olive baboon & Papio anubis & \\
\hline Red colobus & Procolobus badius & $\begin{array}{l}\text { Lower Risk: near } \\
\text { threatened }\end{array}$ \\
\hline $\begin{array}{l}\text { Pennant's red } \\
\text { colobus }\end{array}$ & Procolobus pennanti & \\
\hline \multicolumn{3}{|l|}{ Family: Hominidae } \\
\hline Gorilla & Gorilla gorilla & Endangered (A2cd) \\
\hline $\begin{array}{l}\text { Pygmy } \\
\text { chimpanzee }\end{array}$ & Pan paniscus & Endangered (A2cd) \\
\hline Chimpanzee & Pan troglodytes & Endangered (A2cd) \\
\hline
\end{tabular}

Species are listed alphabetically by scientific name, under their respective families. Both scientific and common nomenclature follows Kingdon (1997) and threat categories are taken from IUCN (1996). 
hunting pressure, if their numbers fall to levels that make hunting them no longer viable, this could have significant repercussions on village economies and individual hunters.

A comparison of Figs 1 and 2 shows that the market share of primate carcasses exceeds that found at the village level, and this is probably due to the hunting techniques involved. Village hunting, in general, tends to be based on snaring (Dethier, 1995; Vanwijnsberghe, 1996; Wildlife Conservation Society, 1996; Delvingt, 1997), accounting for a maximum of 84 per cent of all kills (Wildlife Conservation Society, 1996), and this affects arboreal primates less. (Although, Noss [1998] reported the use of snares set in trees specifically for monkeys in CAR.) The data in Fig. 3, from a logging camp in Gabon (Boussougou, 1994), are therefore significant despite being from a single source. In this case the percentage of primates is much greater than in Figs 1 and 2, and this may be explained by the fact that logging companies often employ commercial hunters to provide their workers with protein, while allowing the export of more meat by specialized immigrant hunters. These hunters rely more heavily on rifles, and often hunt during the day. Primates, which are most susceptible to this form of hunting (99 per cent were taken using this method in Diba, Congo [Delvingt, 1997]), are taken at high levels. Research in the Lobéké region of Cameroon also showed that off-take by commercial hunters, such as those that operate in concessions, was 10 times that of local subsistence hunters (Wildlife Conservation Society, 1996).

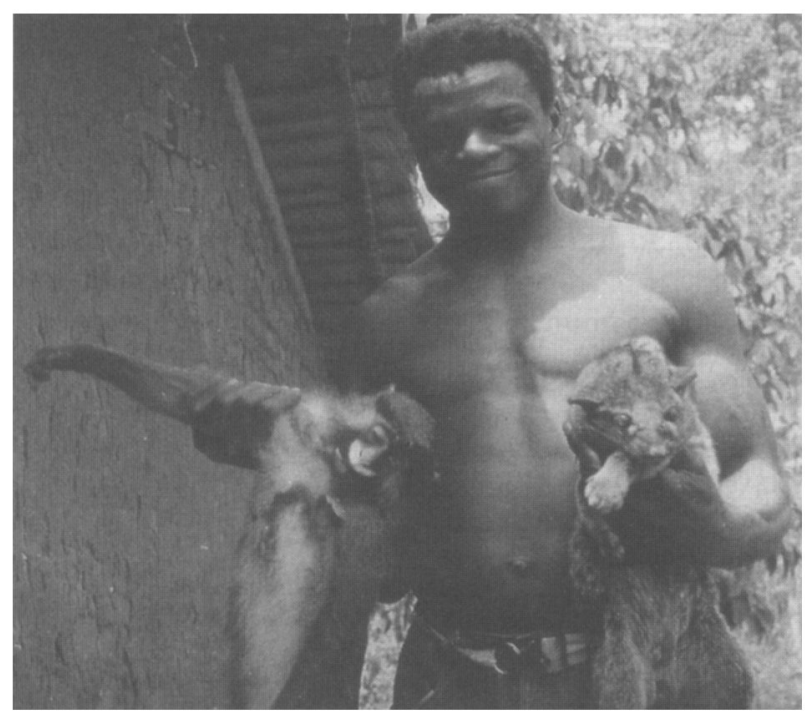

Plate 3 A day's catch for this village hunter consists of a moustached monkey Cercopithecus cephus and an African palm civet Nandinia binotata (ECOFAC Programme: University of Gembloux).
The effect of commercial bushmeat trade on other taxa

The bushmeat trade threatens many species, so it is inappropriate to examine primate hunting in isolation (S. Gartlan, pers. comm.). Market studies throughout Central Africa show that an enormous volume of meat is being taken from some of the most biodiverse forests in the world (Anstey, 1991; Caldecott et al., 1994; Steel, 1994; Bennett Hennessey, 1995; Dethier, 1995; Fa et al., 1995; Malonga, 1996), and this indicates the scale and seriousness of an ecological problem that will escalate if the commercial trade goes unchecked. Figures 1-3 show that the vast majority of bushmeat comes from animals other than primates, and therefore concern and conservation efforts should be spread across taxa.

Duikers represented three-quarters of the bushmeat harvest in Liberia (Anstey, 1991), which seems to be typical of the commercial trade in West and Central Africa, where the most common animals, as well as pest species and animals found around human habitation, are those that appear most frequently for sale. Rodents comprised 32 per cent of market carcasses in Equatorial Guinea (Fa et al., 1995), and these, plus a single species of artiodactyl, the blue duiker Cephalophus monticola accounted for over 50 per cent of the total (Juste et al., 1995; Plate 4). The artiodactyls in general, i.e. bush pigs Potamochoeros larvatus, water chevrotain Hyemoschus aquaticus, buffalo Syncerus caffer and duikers represent the majority of animals traded in the Lobéké region of Cameroon, whether hunted by local subsistence hunters or commercial hunters (Wildlife Conservation Society, 1996). Duikers are often assumed to be relatively resilient to hunting pressure, but this does not mean that the current levels of killing involved are sustainable, and there are recorded examples of over-exploitation of this group (Wilkie \& Finn, 1990; Fa et al., 1995; Wildlife Conservation Society, 1996; Delvingt, 1997; Plate 5).

Other species are also being affected and becoming locally extinct as a result of the indirect effects of snaring, e.g. golden cat Profelis aurata and leopard Panthera pardus (Wilkie \& Finn, 1990; Stromayer \& Ekobo, 1991; Gadsby \& Jenkins, 1992; Eves, 1996). The giant pangolin Smutsia gigantea is not able to withstand hunting pressure because of its low fecundity and ease of capture (Bennett Hennessey, 1995). The slendersnouted crocodile Crocodylus cataphractus might already be extinct in parts of its range because of hunting pressure (Behra, 1987), but its status remains unknown (J. Perran Ross, pers. comm.). Tens of thousands of the more abundant dwarf crocodile Osteolaemus tetraspis are sold at local markets each year (Behra, 1993). Hunting of elephants for meat is also a cause of major concern 


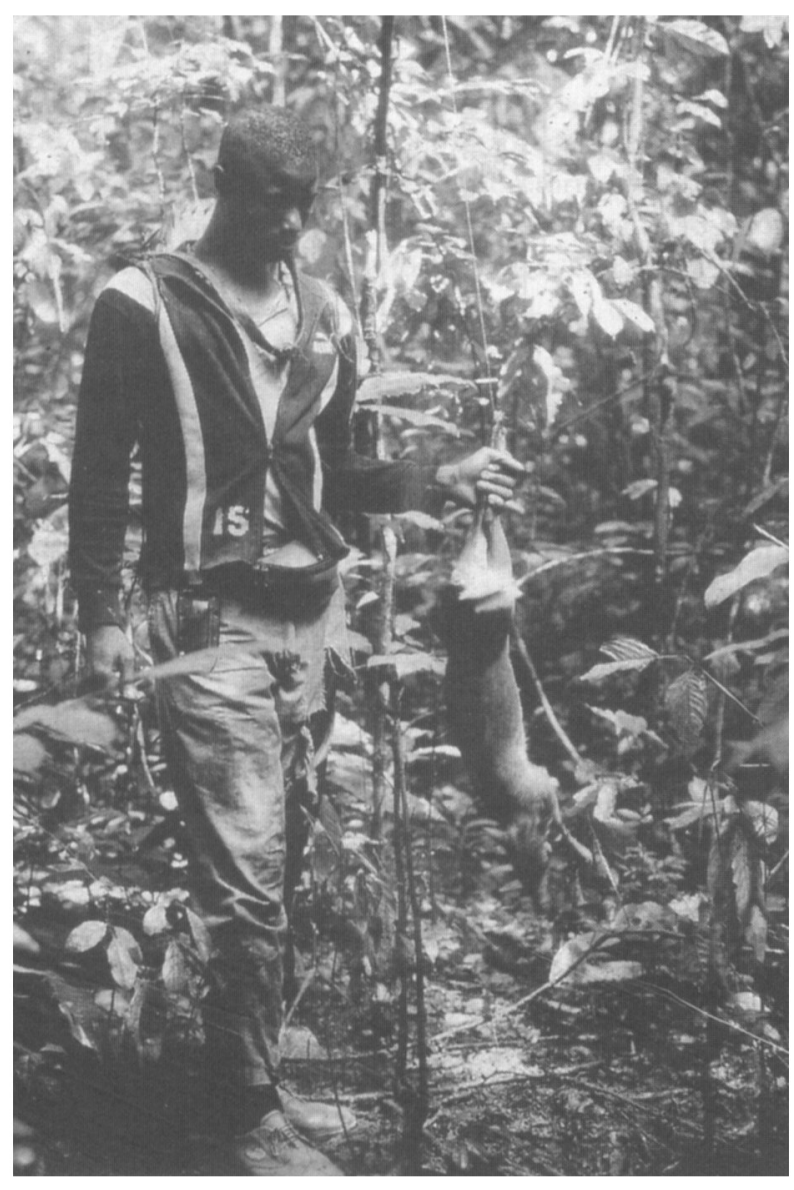

Plate 4 The blue duiker Cephalophus monticola is one of the most commonly caught species (ECOFAC Programme: University of Gembloux).

and has already caused local extinctions, according to several authors (Fay, 1989; Blake, 1994; Bennett Hennessey, 1995; Eves, 1996; Vanwijnsberghe, 1996).

\section{Recommendations to reduce supply and demand of bushmeat}

We present here a brief review of some of the recommendations being proposed to reduce both the supply of and demand for bushmeat (see Fig. 5 for mechanisms of how the bushmeat trade works). It is possible to divide the bushmeat trade into two groups, local supply and commercial supply, and we propose the definitions below for the analysis of the commercial trade and its mitigating measures.

1 Local supply: the supply of meat from local hunters to markets, not involving immigrant workers. (This is still a part of the commercial trade and distinct from subsistence hunting and consumption, although in practice it may represent the spare meat generated from subsistence hunting.)
2 Commercial supply: the supply of bushmeat to urban centres from logging concessions and other areas, often involving large numbers of immigrant workers and often purely for commercial purposes.

\section{Reducing local supply}

\section{Control of snaring}

Controlling the use of snares is very important because they are not species-specific, being capable of capturing all species of forest mammals (except elephants), birds and reptiles, and because they are wasteful (Noss, 1998). Control could include a restriction on the distance snares can be set from villages, because wastage as a result of decomposition increases with distance from settlements (Muchaal \& Ngandjui, 1995). This measure could be combined with increased, systematic checking of snares, which would also reduce losses to scavengers and secondary deaths when injured animals escape (Noss, 1998). In many countries in the region, snaring is illegal. However, where

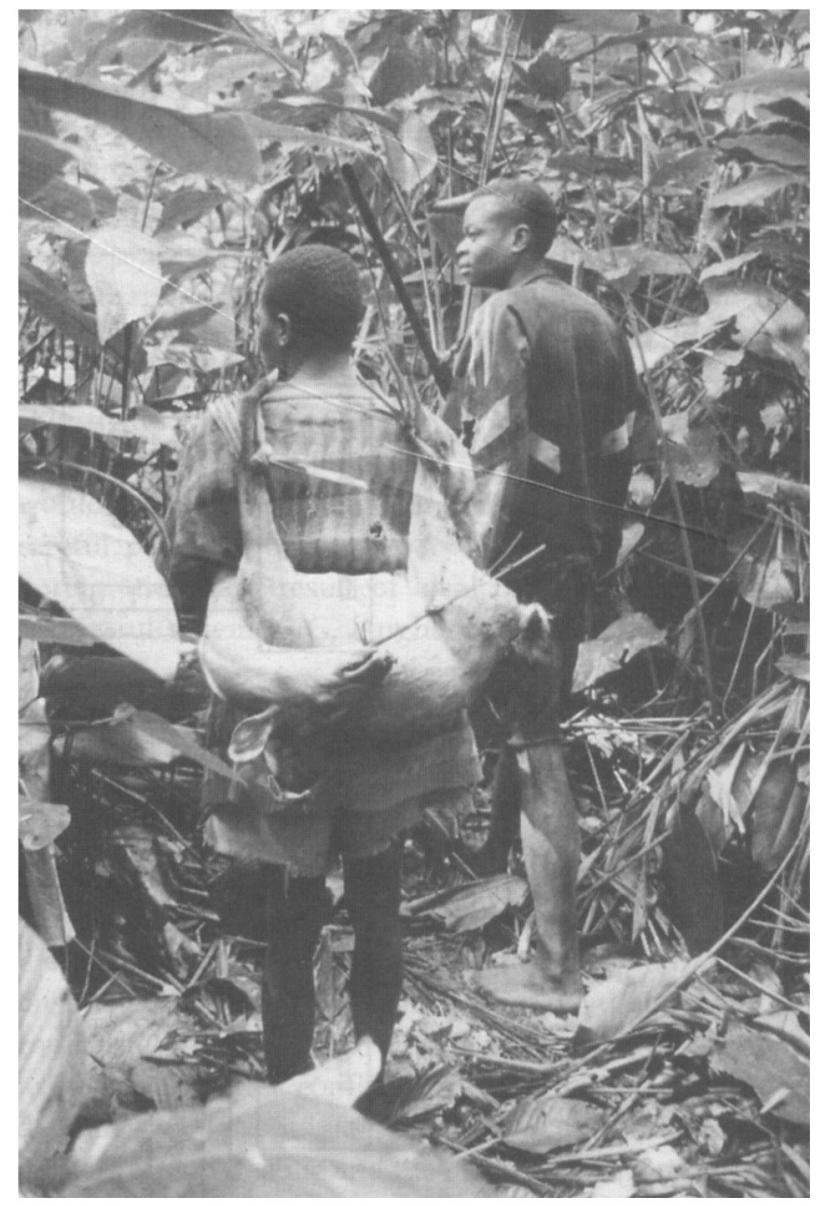

Plate 5 This white-bellied duiker Cephalophus leucogaster was shot during a hunting trip and is one of the larger, rarer forest antelopes that are particularly at risk from the commercial bushmeat trade (ECOFAC Programme: University of Gembloux). 


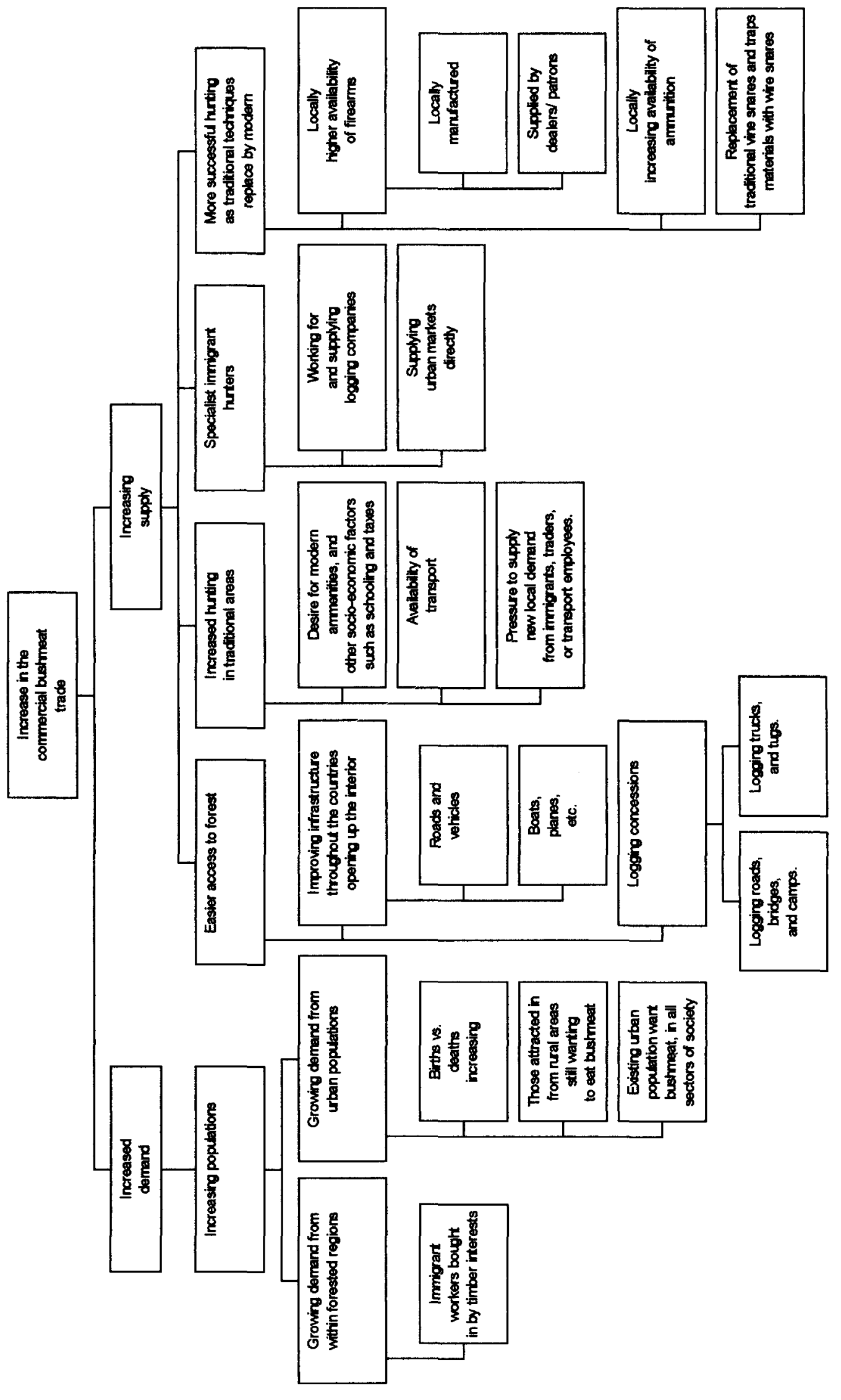

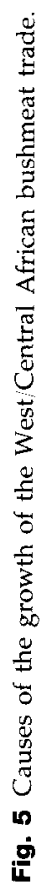


snaring continues, consideration of such measures must be an integral part of any conservation scheme and conservationists must try to agree on practical compromises with local residents (Noss, 1998). Whatever measures are taken, monitoring of snaring can also provide a useful tool for measuring success of community conservation efforts (Lewis \& Phiri, 1998).

\section{Quota systems}

The basic lack of information on the population dynamics of the main target species makes the establishment of quotas difficult. In order to determine sustainable levels of hunting, information on population densities, reproductive potential and rate of offtake are needed (Robinson \& Redford, 1994). There is an urgent need for basic ecological research on the main bushmeat species, such as porcupines, rats and smaller duikers, and in part this need is being met by current research. Furthermore, quota systems could be more effective if hunters were encouraged to sell directly to markets, missing out the middlemen who currently take most of the profit (Bennett Hennessey, 1995). Hunters could then obtain realistic prices for the meat and would be able to make a living while selling less meat. This would mean that revenue for government taxes would still be payable at the local level as a direct consequence of hunting. It would have the effect of promoting the idea of sustainable use at community level and could start to meet some of the discrepancies between short-term gain and long-term management schemes highlighted by Noss (1997). The system could be facilitated by excluding commercial sponsors of local hunters (i.e. middlemen) and assisting in the establishment of local co-operatives with the ability to sell meat directly to markets. These co-operatives could also collectively own and manage guns and ammunition, as well as monitor catches.

\section{Local enforcement}

Implementing quotas or existing regulations and promoting alternative snaring schemes require fundamental changes in the attitudes of stakeholders, and an increase in the ability and willingness of local authorities to enforce regulations. Local people should be encouraged to implement quota systems: through economic incentives, such as increasing local wealth to discourage excessive or illegal hunting; through education by raising public awareness of the issues involved; and through existing cultural etiquette by encouraging social traditions that preclude selfish, individual hunting. It may be possible to integrate the traditional taboos of certain sections of society against eating certain species. These taboos may be related to perceived health risks (Vanwijnsberghe, 1996); the health of future children (Muchaal \& Ngandjui, 1995); religion (Oates \& Davies, 1986; Harcourt \& Ellerton, 1995); or physical and behavioural similarity of apes to humans (Bennett Hennessey, 1995; Vanwijnsberghe, 1996). However, people in many of the areas in which these beliefs were once strongly held are becoming less strict in their adherence as a result of the commercialization of hunting. For example, in villages where bush pig and buffalo carcasses had to be shared in the past, only the head of the animal is now given to the community (Infield, 1988).

\section{Promotion of ownership}

There must be sufficient incentive to conserve resources at a local level, and one of the problems at the moment is that local people do not have the ability to exclude outsiders from exploiting their resource base (Noss, 1997). Noss stated that in Central African Republic all land is government-owned and local people have no say in the awarding of concessions or access to land for safari hunting. One way to foster interest in sustainable long-term resource use might be to include land and resource tenure as part of community conservation efforts. The CAMPFIRE programme (Communal Areas Management Programme for Indigenous Resources) has taken this approach in Zimbabwe with considerable success. CAMPFIRE offers an alternative: proprietorship and decentralized management of natural resources by rural communities, based on the premise that if people 'own' resources and those resources are given a value, they will be used sustainably (Child et al., 1997). This does not, however, guarantee that subsequent community decisions would promote conservation. Close monitoring and careful planning are necessary to prevent subsequent immigration as a result of local prosperity caused by successful schemes (G. Hughes, pers. comm.).

\section{Taxation}

Reducing the demand for bushmeat could be accomplished by making the price of bushmeat rise relative to alternative sources of meat, while ensuring that these alternatives are produced in sufficient quantity to meet demand. One way to do this would be by taxing the transportation of bushmeat, with taxes targeted at bushmeat traders. This would then avoid the need to confiscate bushmeat and the inherent problem of what to do with it after confiscation (Wilkie et al., 1998). If demand and profits fall, the price that traders pay hunters would decline and the income from hunting will also decline. To compensate local communities for the loss of revenue-generating opportunities associated with a tax on bushmeat transportation, a proportion of taxes could be returned to the local community in the form of 
social services. This assumes legal authority and political will to return taxes to local communities, as well as a switch in attitudes and preferences away from bushmeat towards suitable alternatives.

\section{Alternative protein sources}

Although the topic is not covered in detail in this paper, there are a number of options available to curb the demand for bushmeat as a subsistence protein. Eves (1996) concluded that 'further study ... is necessary in order to determine ... market potential for alternative sources of protein'. At the local level, one option is to encourage intensive breeding of cane rats Thryonomys swinderianus and Emin's rat Cricetomys emini, which are already being eaten in large quantities. To date, attempts at intensive breeding have had mixed success (Heymans, 1994) and they have not turned out to be the solution that was hoped for. Pilot studies on these and other larger species such as blue duikers, sitatunga Tragelaphus spekei and red-river forest hogs Potamochoerus porcus are still being attempted (Jori, 1997), but it is questionable whether wild animals with limited reproductive potential and territorial behaviour have the capacity to meet the demands from urban markets. Perhaps cattle may be a more feasible alternative in some places, such as the highlands of Bioko, where there is no tsetse fly, where the land has already been cleared and where cattle ranching was practised in the past under Portuguese rule (J. Fa, pers. comm.). Beef could become a 'civilized' and hygienic alternative to bushmeat in cities across the region, as it is currently in some Muslim areas. Unfortunately, bushmeat is favoured by urban populations because it is considered tastier than beef and is culturally valued, with high prices being paid as a result. Therefore, it is only in conjunction with awareness and education programmes that changes in urban, consumer attitudes and buying habits could be achieved.

\section{Protection of threatened species and their habitats}

Management strategies need to include measures to prevent species becoming extinct, including the total protection of endangered species and a total ban on hunting in given core areas. These core areas may be in national parks or, at a local level, could involve the setting up of no-hunting areas to ensure future supplies of bushmeat. Again, effective local and national enforcement of existing game laws is a prerequisite, together with the creation of new legislation if necessary and appropriate.

Wildlife is used extensively as a food source in Africa and, while sustainable harvesting of some species will be necessary in conjunction with animal husbandry, the wide range of non-governmental organizations and indi- vidual proponents of this strategy also stress that realistic, and effective, protected-area schemes must remain one of the cornerstone conservation tools.

A key variable in the success of protected areas is the size of the core area. This has been shown to be critical from a hunting standpoint, as illustrated by a study in Okapi Game Reserve, DRC, where total off-take exceeded production in the totally protected central zone because the latter was too small (Wilkie et al., 1998). This contrasts with the situation in Garamba National Park, DRC, where large mammal populations were well conserved as a result of the large core area where there was no hunting activity (de Merode, 1997). Essentially, core areas should act as 'sources' for the 'sink' areas where hunting can take place, in order to ensure overall sustainability in a community conservation framework (Bodmer, in press). The promotion of tighter zoning systems for hunting in buffer zones around protected areas could be one way to reduce local extinctions and ensure there are source areas to supply more game (R. Barnwell, R. Carroll, J. Fa \& M. Fay, pers. comms.).

\section{Government enforcement}

The establishment of hunting seasons or reserves to stock hunting areas would have local support in many areas, but would also require government enforcement (Gadsby \& Jenkins, 1992). National governments, therefore, need to display the determination to implement a suite of compatible and coherent measures to control the commercial trade effectively. Furthermore, hunters and other stakeholders need to be involved in the conservation-planning process, because they have interests in maintaining a level of sustainable hunting that ensures that the huge revenue brought in from bushmeat hunting each year is maintained. Realistic conservation policies may mean the inevitable decline in the status of some species as a result of their loss at some local levels (Anstey, 1991). However, the key is a pragmatic approach because, given limited economic and man-power resources, full protection will have to be concentrated on priority areas identified by key stakeholders, particularly governmental organizations. There is an urgent need for the nations concerned to define the mechanisms with which to implement these measures in order to promote country-specific strategies. This is the only way to effect long-term conservation.

\section{Possible avenues to reduce/limit commercial supply}

Logging - influencing logging companies, trade organizations, governments and consumers

The commercial supply of bushmeat is linked closely to the operations of logging companies. Action is needed, therefore, to ensure that logging practices are 
both sustainable in themselves and also do not have adverse impacts on wildlife. This will require influencing logging companies, trade organizations, governments and consumers.

In 1990, the UK House of Lords, having reviewed EU policy on tropical forests, stated that a more discriminatory approach to tropical hardwood imports could encourage trade in high-value products from sustainable sources and discourage other imports (Rice \& Counsell, 1993). Trade organizations such as the International Timber Trading Organization have not been able so far to regulate, or. have been unwilling to interfere with, the import of timber, or the practices of European-owned logging firms. However, consumer pressure and the policies of the national governments in Africa, as well as competition with Asian rivals, will mean that European companies will have to try to make their practices sustainable and therefore more acceptable. This includes limiting their role in the commercial bushmeat trade and reducing commercial supply. It is possible that competition from Asian firms could lead to deterioration in European practices in an effort to increase profit margins. None the less, one of the ways to increase profit margins would be to meet the demand for sustainably produced tropical timber.

\section{Timber certification}

A few companies are already making attempts to do something about their role in the bushmeat trade as part of the timber certification process, through organizations such as the Forest Stewardship Council (FSC). However, more needs to be done, and the opportunity exists for non-governmental organizations, governments, the logging industry and local people involved in hunting to try and work out some solutions. If this does not begin to happen in the next few years, much of the incredible wealth of life in the tropical moist forests of Africa will be lost.

\section{Codes of conduct}

One way to try to effect change in the logging industry would be to encourage logging companies to participate in the formulation of national codes of conduct for logging practice under the existing structure of national laws. Such codes of conduct could include measures to ensure that: there is no export of bushmeat from logging concessions; companies provide sufficient meat for the work force so that there is no need for additional hunting; and on leaving a concession, when timber operations have been completed, further vehicle access is impeded by blocking roads and bridges (Bowen-Jones, 1998). These codes could be introduced under the aegis of mechanisms of such organizations as the FSC national councils.

\section{International governmental action}

There is also a strong argument for the French Government, among others, to promote the adoption of certification or other measures and promote this to national governments within Africa. This may help to safeguard their own firms from the Asian competitors who are already capable of pushing European firms out.

\section{Reform of concession allocation}

There are obstructions to such long-term strategies, in the form of short-term economics. Most logging concessions are currently allocated for terms that are shorter than the minimum time that forests should be left before recutting, and this encourages cutting cycles that are too short (Gartland, 1990). However, many companies do view their tenure of concessions in the longer term, so there may be a way to promote more sustainable logging. However, with the emergence of Asian companies, such perceptions may be changing.

\section{Conclusions}

Within the geographical region of Central and West Africa, all major urban centres are foci for the growing trade in wild-animal meat. With the suite of options mentioned above for alternative protein supply and rationalized off-take of wild animals, plus a reduction of urban demand, and supply from other sources, there is no reason why a system that meets the true definition of sustainability cannot evolve. In order to do this it is fundamental that there is active participation from the countries involved, at all stages of planning and implementation. However, many of the suggestions above will require a large amount of external control or the introduction of new ideas, such as: controlling the use of snares through restricting trap-line distances; the implementation of quota systems; encouraging hunters to sell directly to markets; changes in the stakeholders' attitudes; zoning in and around protected areas; and alternative livestock systems. Sustainable hunting schemes will require technical input from biologists as well as local support from communities (Bodmer, in press). A necessary complementary approach, which will make this more manageable, is to promote traditional social hierarchies where suitable, and to strengthen ownership of village hunting areas to encourage local enforcement.

In order to bring about long-term changes in hunting patterns and provide the sustainability of an important component of the economies of Central and West African countries, fundamental changes are needed in the way that natural resources are viewed. In any local, national or regional scheme that tries to make the connection between 'conservation' and long- 
term income generation by limiting commercial hunting, the most important factor has to be attitude. Without education, without the full participation of stakeholders to make solutions as appropriate to individual situations as possible, and without successful schemes that allow expectations to be fulfilled, such as alternative sources of income and generation of alternative protein sources, attitudes will not change and there will be no long-term gains.

There is no shortage of ideas on how to bring the bushmeat trade under control, and it is within this wide framework that NGOs can be of most value. However, Central and West African countries currently lack the willingness and/or ability to implement the changes needed, and the funds necessary to do this, be they from the governments themselves or from external sources. Without the huge investment and attitude shifts within consumer groups that are needed to make any significant change for the better in the forests of West and Central Africa, defaunation will continue unabated, and the biodiversity of the region will be lost forever. Technological advances and the free market economy have usurped traditional methods and attitudes to hunting, causing pressure on native wildlife to increase beyond the threshold of sustainability. Local extirpations will become regional extinctions. The result will be fully forested areas devoid of their faunal component-stripped of their wildlife by the commercial bushmeat trade.

\section{Acknowledgements}

The authors would like to thank the following people for their help and encouragement when preparing this paper: Abigail Entwistle, Martin Hollands and Jamison Suter at Fauna \& Flora International; and John $\mathrm{Fa}$ at Jersey Wildlife Preservation Trust. In addition, our gratitude is extended to all those people who commented on the issues discussed, and in so doing helped to formulate the ideas presented on mitigating the effects of the bushmeat trade.

\section{References}

Alvard, M. (1995) Shotguns and sustainable hunting in the Neotropics. Oryx, 29(1), 58-65.

Ammann, K. (1998) The Conservation Status of the Bonobo in the 1-million hectare SIFORZAL/DANZER Logging Concession in Central Congo. Unpublished report, World Society for the Protection of Animals, London, UK.

Anstey, S. (1991) Wildlife Utilisation in Liberia. World Wide Fund For Nature/Liberian Forestry Development Authority survey report. WWF International, Gland, Switzerland.
Basabose, K., Mbake, S. \& Yamagiwa, J. (1995) Research and conservation of eastern lowland gorillas in the KahuziBiega National Park, Zaire. Gorilla Conservation News, 9, 11-12. Wildlife Conservation Society, New York, USA.

Behra, O. (1987) Etude de repartition des populations de crocodiles du Congo, du Gabon et de la RCA. 1eme, 2eme et 3eme partie: Gabon. Secretariat de la Faune et de la Flore, Museum National d'Histoire Naturelle de Paris, Paris, France.

Behra, O. (1993) Cameroon FAO crocodile management project. Crocodile Specialist Group Newsletter, 12(1), 16.

Bennett Hennessey, A. (1995) A Study of the Meat Trade in Ouesso, Republic of Congo. Wildlife Conservation Society/Deutsche Gesellschaft für Technische Zusammenarbeit (GTZ), New York, USA.

Blake, S. (1993) A reconnaissance of the Likoula swamps of Northern Congo and its implications for conservation. MSc thesis, University of Edinburgh.

Blake, S. (1994) A Reconnaissance Survey in the Kabo Logging Concession south of the Nouable-Ndoke National Park, North Congo. Wildlife Conservation Society, New York, USA.

Bodmer, R. (in press). Sustainable use of Amazonian mammals: implications for community-based protected areas. In Future Priorities for Conserving Mammalian Diversity (eds A. C. Entwistle and N. A. Dunstone), Cambridge University Press, Cambridge.

Boussougou, R. (1994) Estimation de la Pression de Autour d'un camp forestier au Gabon. L'Ecole des Eaux et Forêts, Libreville, Gabon.

Bowen-Jones, E. (1998) A Review of the Commercial Bushmeat Trade with Emphasis on Central/West Africa and the Great Apes. Ape Alliance, London, UK.

Butynski, T.M. \& Koster, H. (1994) Distribution and conservation status of primates in Bioko Island, Equatorial Guinea. Biodiversity and Conservation, 3, 893-909.

Caldecott, J.O., Jenkins, M.D., Johnson, T. \& Groombridge, B. (1994) Priorities for Conserving Global Species Richness and Endemism. World Conservation Monitoring Centre, World Conservation Press, Cambridge, UK.

Child, B., Ward, S. \& Tavengwa, T. (1997) Zimbabwe's CAMPFIRE Programme: Natural Resource Management by the People. IUCN-ROSA, Environmental Issues Series No. 2, IUCN Regional Office for Southern Africa, Harare, Zimbabwe.

Delvingt, W. (1997) 'La Chasse Villageoise'. Synthèse régional des Etudes réalisées durant la première phase du Programme ECOFAC au Cameroun, au Congo et en République Centrafricaine. ECOFAC/AGRECO, Brussels, Belgium.

Dethier, M. (1995) Etude du chasse. ECOFAC/AGRECO, Brussels, Belgium.

Eves, H.E. (1996) Socio-economic study 1996 Nouable-Ndoki National Park Congo. Draft documents submitted to Wildlife Conservation Society, New York, USA.

Fa, J.E. (in press) Hunted animals in Bioko island, West Africa: sustainability and future. In Sustainability of Hunting in Tropical Forests (eds J. G. Robinson and E. Bennett), Columbia University Press, Columbia, USA.

Fa, J.E., Juste, J., Perez del Val, J. \& Castroviejo, J. (1995) Impact of market hunting on mammal species in Equatorial Guinea. Conservation Biology, 9(5), 1107-1115. 
Fay, J.M. (1989) Partial completion of a census of the western lowland gorilla (Gorilla g. gorilla Savage and Wyman) in southwestern Central African Republic. Mammalia, 53(2), 203-215.

Gadsby, E.L. (1990) The Status and Distribution of the Drill (Mandrillus leucophaeus) in Nigeria. Report to Wildlife Conservation International, WWF (US), WWF (UK) and the Nigerian Government.

Gadsby, E.L. \& Jenkins, P.D. (1992) Report on Hunting in the Proposed Etinde Forest Reserve. Cameroon.

Gartland, S. (1990) Practical constraints on sustainable logging in Cameroon. In Proceedings of the Conference sur la Conservation et l'Utilization Rationalle de la Forêt dense d'Afrique Centrale et de L'Ouest, 5-9 November 1990. African Development Bank/IUCN/World Bank, Washington, DC.

Gippoliti, S. \& Dellomo, G. (1995) Status and conservation of the chimpanzee (Pan troglodytes verus) in Guinea-Bissau. African Primates, 1(1), 3-5.

Goldsmith, M.L. (1995) Ranging and grouping patterns of western lowland gorillas (Gorilla g. gorilla) in the Central African Republic. Gorilla Conservation News, 9, 5-6. Wildlife Conservation Society, New York.

Hall, J. (1993) Report on the Strategic Planning Mission for the Creation of a Protected Area in the Lobéké Region of South-eastern Cameroon: Assessment of Timber Exploitation, Safari Hunting and Preliminary Vegetation Analysis. Wildlife Conservation Society, New York, USA.

Harcourt, A.H. (1980) Gorilla-eaters of Gabon. Oryx, 15(3), 248-251.

Harcourt, A.H. (1995) Is the gorilla a threatened species? How should we judge? Biological Conservation, 7, 134-142.

Harcourt, C.S. \& Ellerton, N.G. (1995) A Brief Look at the Primates of Gashaka Gumti National Park, Nigeria. World Wide Fund for Nature-UK and Nigerian Conservation Foundation, Chester, UK.

Hart, J.A. (1978) From subsistence to market: a case study of the Mbuti net hunters. Human Ecology, 6, 323-353.

Hart, T.B. \& Hart, J.A. (1986) The ecological basis of hunter-gatherer subsistence in African rainforests: the Mbuti of eastern Zaire. Human Ecology, 14, 29-55.

Heymans, J.C. (1994) Utilisation rationalle de la Faune sauvage-elevage de petit Gibier. Republique de Guinee Equatoriale. Ministère de l'Agriculture, Pêche et Alimentation. Groupement Agrer and Agriconsulting-CIRAD Forêt, Brussels, Belgium. Infield, M. (1988) Hunting, Trapping and Fishing in Villages within and on the Periphery of the Korup National Park. World Wildlife Fund report, Washington DC, USA.

IUCN (1996) 1996 IUCN Red List of Threatened Animals. IUCN, Gland, Switzerland.

Jori, F. (1997) Etude sur la Faisabilité de l'Elevage commercial d'Espèces sauvages au Gabon. World Wide Fund For Nature-Gabon, Libreville, Gabon.

Juste, J., Fa, J.E., Perez del Val, J. \& Castroviejo, J. (1995) Market dynamics of bushmeat species in Equatorial Guinea. Journal of Applied Ecology, 32, 454-467.

Kano, T. \& Asato, R. (1994) Hunting pressure on chimpanzees and gorillas in the Motaba river area, northeastern Congo. African Study Monographs, 15(3), $143-162$.
Kemf, E. \& Wilson, A. (1997) Great Apes in the Wild. World Wide Fund For Nature Status Report, Gland, Switzerland.

King, S. (1994) Utilisation of wildlife in Bakossiland, West Cameroon, with particular reference to primates. TRAFFIC Bulletin, 14(2), 63-73.

Kingdon, J. (1997) The Kingdon Guide to African Mammals. Academic Press, London.

Lahm, S. (1996) Gabon's village hunting: assessing its impact. African Primates, 2(1), 23-24.

Lewis, D.M. \& Phiri, A (1998) Wildlife snaring - an indicator of community response to a community-based conservation project. Oryx, 32(2), 111-121.

Malonga, R. (1996) Circuit commercial de la Viande de Chasse a Brazzaville. Wildlife Conservation Society/Global Environment Facility, New York, USA.

McFarland, K. (1994) Update on gorillas in Cross River State, Nigeria. Gorilla Conservation News, 8, 13-14.

de Merode, E. (1997) Interim Report on the APFT Project on the Analysis of Data Collected in the Communities surrounding Garamba National Park, Democratic Republic of Congo, for a Study of Bushmeat Utilisation amongst the Azande. University College, London, UK.

Muchaal, P.K. \& Ngandjui, G. (1995) Secteur ouest de la Reserve de Faune du Dja (Cameroun): Evaluation de l'Impact de la Chasse villageoise sur les Populations Animales et Propositions d'Amenagement en Vue d'une Exploitation rationnelle. Programme de Conservation et d'Utilisation Rationalle des Ecosystems Forestiers en Afrique Centrale (ECOFAC)/Ministry of Environment and Forests, Yaounde, Cameroon.

Njiforti, H.L. (1996) Preferences and present demand for bushmeat in north Cameroon: some implications for wildlife conservation. Experimental Conservation, 23(2), $149-155$.

Noss, A.J. (1997) Challenges to nature conservation with community development in central African forests. Oryx, 31(3), 180-187.

Noss, A.J. (1998) The impacts of cable snare hunting on wildlife populations in the forests of the Central African Republic. Conservation Biology, 12(2), 390-397.

Oates, J.F. \& Davies, A.G. (1986) Primate conservation in West Africa. In Current Issues in Primate Conservation (ed. M. F. Stevenson). Primate Eye, 29(Suppl.), 20-24.

Pearce, J. (1996) Wildlife and Timber Exploitation in Gabon: A Case Study of the Leroy Concession, Foret des Abeilles. World Society for the Protection of Animals, London, UK.

Pearce, J. \& Ammann, K. (1995) Slaughter of the Apes: How the Tropical Timber Industry is Devouring Africas Great Apes. World Society for the Protection of Animals, London, UK.

Prescott, J., Rapley, W.A. \& Mewondo, J.M. (1994) Statut de chimpanzees et gorilles au Cameroun. Le Courier de la Nature, 148, 34-41.

Redmond, I. (1989) Trade in Gorillas and Other Primates in the People's Republic of Congo. Report to International Primate Protection League, UK.

Rice, T. \& Counsell, S. (1993) Forests Foregone: The European Community's Trade in Tropical Timbers and the Destruction of the Rainforests. Friends of the Earth report, London, UK. 
Robinson, J.G. (1995) Hunting Wildlife in Forest Patches: An Ephemeral Resource. Wildlife Conservation Society, New York, USA.

Robinson, J.G. \& Bennett, E. (eds) (in press) Sustainability of Hunting in Tropical Forests. Columbia University Press, Columbia, USA.

Robinson, J.G. \& Redford, K.H. (1994) Measuring the sustainability of hunting in tropical forests. Oryx, 28(4), 249-256.

Sabater, J. (1981) Exploitation of gorillas (Gorilla g. gorilla) Savage and Wymann 1847, in Rio Muni, Republic of Equatorial Guinea, W. Africa. Biological Conservation, 19, 131-140.

Sayer, J.A., Harcourt, C.S. \& Collins, N.M. (1992) The Conservation Atlas of Tropical Forests: Africa. IUCN/Macmillan, Basingstoke, UK.

Steel, E.A. (1994) Study of the Value and Volume of Bushmeat Commerce in Gabon. WWF Programme pour le Gabon, Libreville, Gabon.

Stromayer, K.A.K. \& Ekobo, A. (1991) Biological Surveys of Southeastern Cameroon. European Union/Wildlife Conservation Society, New York, USA.

Tutin, C.E.G. \& Fernandez, M. (1984) Nation-wide census of gorilla (Gorilla g. gorilla) and chimpanzee (Pan t. troglodytes) populations in Gabon. American Journal of Primatology, 6, 313-336.

Usongo, L. \& Curran, B. (1996) Le commerce de la viande de chasse au sud-est du Cameroun dans la region trinationale. African Primates, 2(1), 2-5.

Vanwijnsberghe, S. (1996) Etude sur la Chasse villageoise aux Environs au Parc d'Odzala. Programme de Conservation et d'Utilisation Rationalle des Ecosystems Forestiers en Afrique Central (ECOFAC)/Agrer and Agriconsulting (AGRECO), Brussels, Belgium.

White, L.J.T. (1994) The effect of commercial mechanised selective logging on a transect in lowland rainforest in the Lopé Reserve, Gabon. Journal of Tropical Ecology, 10, 313-322.
Wildlife Conservation Society (1996) The Lobéké Forest: Southeast Cameroon. Summary of Activities Period 1988-1995. Wildlife Conservation Society, New York, USA.

Wilkie, D.S. \& Finn, J.T. (1990) Slash-burn cultivation and mammal abundance in the Ituri Forest, Zaire. Biotropica, 22(1), 90-99.

Wilkie, D.S., Sidle, J.G. \& Boundzanga, G.C. (1992) Mechanised logging, market hunting, and a bank loan in Congo. Conservation Biology, 6(4), 570-580.

Wilkie, D.S., Curran, B., Tshombe, R. \& Morelli, G.A. (1998) Managing bushmeat hunting in Okapi Wildlife Reserve, Democratic Republic of Congo. Oryx, 32(2), 131-144.

Wilson, C.C. \& Wilson, W.D. (1991) La chasse traditionelle et commercial dans le sud-oueste du Congo. Tauraco Research Report, 4, 279-289.

\section{Biographical sketches}

Evan Bowen-Jones studied for an MPhil in Zoology at Cambridge University. He has worked in West Africa, Central America, the South Pacific and Australia on a wide range of taxa and issues, publishing on many of these subjects. He is currently working for Fauna \& Flora International where he is involved in research, and project development and management on biodiversity and sustainable-use issues, including FFI's bushmeat programme.

Stephanie Pendry was the Species in Trade co-ordinator at Fauna \& Flora International when this paper was written, and was involved in the development of the bushmeat programme and wildlife-trade issues. She gained an MSc in conservation biology from the Durrell Institute for Conservation and Ecology, and has worked in East Africa, Southern Africa and South East Asia on a variety of conservation projects. She now works for TRAFFIC International in Cambridge. 